\title{
Fiber Effects on Microhistological Analysis
}

\author{
HASHIM K. MUKHTAR AND RICHARD M. HANSEN
}

\begin{abstract}
A study was done to illustrate the influence of fiber on the ratio of estimated to actual dry weight fractions of selected species of grasses, forbs, and shrubs in samples analyzed by microhistological analysis. There was no significant relation between the fiber fraction of the plants and the over or under estimations. Forbs were not generally underestimated any more than were grasses or shrubs. The hypothesis is rejected which states that plants with low fiber values are usually underestimated by the microhistological technique.
\end{abstract}

Microhistological analysis of digestive tract residues has become widely used to determine herbivore diets over the past 2 decades. The references to basic problems and techniques for improving quantification by this technique can be found in Holechek et al. (1982), Holechek and Gross (1982), and Vavra and Holechek (1980). The most important factor among those studied has been "technician training" (Dearden et al. 1972, Holechek et al. 1982).

Voth and Black (1973) and others have assumed that the plant species which are generally succulent, fragile leaved, younger leaved and highly digestible have thin cell walls and thin cuticles. The discernible light patterns a technician sees using a microscope are most often related to light diffracted by cell walls and/or thickening of the cuticle over the leaf surface. Plant species with thick cell walls are more likely to survive microscope slide preparation techniques and/or digestion. However, with proper training microscope technicians may be taught to look for faintly discernible cuticular images and to record them in proportion to their dry weight fraction in mixtures.

We had assumed that with proper training a technician (the senior author) could be taught to accurately estimate the dry weight fractions of forage plants using the microhistological technique. Our hypothesis was that the fiber fraction did not influence the relationship between cell wall constituents (neutral detergent fiber) and the over or underestimation of plant species in mixtures using a microhistological technique.

\section{Materials and Procedures}

The observer (technician) was trained according to the procedure followed in the Composition Analysis Laboratory, Colorado State University. The procedure included: (1) oral description of the technique; (2) study of reports and results utilizing microhistological analyses; (3) demonstration of use of microscope; (4) sample collection, preservation, processing, and grinding; (5) slide preparation procedure according to the method described by Sparks and Malechek (1968) and Flinders and Hansen (1972); and (6) study of epidermal characteristics of different species of plants including sedges, forbs, and grasses.

The aboveground parts were collected for western wheatgrass (Agropyron smithii), sandberg bluegrass (Poa secunda), basin big sagebrush (Artemisia tridentata), and douglas rabbitbrush (Chry-

\footnotetext{
At the time of research, Mukhtar was a graduate student and Hansen was acting department head, Range Science Department, Colorado State University, Fort Collins, Colorado 80523, Telephone (303) 491-6620.

The authors wish to thank T.M. Foppe for her assistance. This study was funded by CSU Experiment Station Project No. 78.

Manuscript received July 1, 1982
}

sothamnus vicidiflorus) from Worland, Wyoming; sand dropseed (Sporobolus cryptandrus) and fireweed summercypress (Kochia scoparia) from Springfield, Colorado; desert globemallow (Sphaeralcea ambigua) from Grand Wash Cliffs, Arizona; and water sedge (Carex aquatilis) from Nome, Alaska. The portions usually eaten by a large herbivore were collected in paper sacks and oven dried at $65^{\circ} \mathrm{C}$. Common names of plants follow Beetle (1970).

Each plant sample was ground in a Wiley Mill through a 20mesh (1-mm opening) screen. Four duplicate samples of 2 grams each were analyzed for neutral detergent fiber(NDF)(Goering and Van Soest 1970). Five reference slides were made of each plant species.

Eight hand compounded mixtures were made using enough material to total 10 grams each. The dry weight portions of each species in each mixture varied from about 0.3 grams to about 5.0 grams. The technican was not told the proportions in these mixtures. Ten microscope slides were made of the variable hand made mixtures.

One hand compounded mixture was made which contained 1 gram dry weight of each plant species. Ten mic roscope slides were made of this mixture. The technician was given these slides and the reference slides of each plant species for study. The technician was told what the slides contained. All slides were made following the method described by Sparks and Malechek (1968) and Flinders and Hansen (1972).

The reference materials were studied microscopically at 100 power magnification using a binocular microscope equipped with phase contrasting lenses, and pencil drawings of the diagnostic characteristics were made.

A "frequency conversion" technique was used, where the presence of identifiable fragments was recorded for each species for each field. The density of fragments for species was obtained directly from a series of calculated tables which convert frequency to density for 20 microscopic fields.

The 10 slides of each mixture were examined twice. Twenty microscopic fields were chosen randomly on horizontal lines along the slide at $45 \mathrm{~mm}, 37 \mathrm{~mm}$, and $30 \mathrm{~mm}$. Only a field of at least 2 identifiable fragments of 1 or 2 species, or a field with one plant fragment occupying at least $80 \%$ of the field, was recorded during the quantification procedure.

The data of both trials were considered as one group, and a paired $t$-test was used to test the hypothesis that there was no significant difference between the estimated relative density and actual percent dry weight of each species $\left(\mathrm{H}_{\mathrm{o}}: \mu \mathrm{d}=0\right.$ ). A regression analysis was done to find the correlation between the estimated relative density and actual percent dry weight using the same data for each species.

Spearman's Rank Correlation Coefficient was used to test the hypotheses that the estimated percent relative density and fiber content of the species are dependent.

\section{Results}

Relative percent densities of most plant species were similar to the actual percent dry weights. However, the mean of the overall estimates of sandberg bluegrass was $5 \%$ lower than the actual percent dry weight $(p<0.05)$. On the other hand, the estimated 
Table 1. Coefficient of determination $\left(\boldsymbol{r}^{2}\right)$, regression coefficients ( $a$ and $b$ ), and percent NDF for the studied plant species 1 .

\begin{tabular}{llll}
\hline \hline Plant species & $\mathrm{Y}=\mathrm{a}+\mathrm{bx}$ & $r^{2}$ & $\mathrm{NDF} \%$ \\
\hline $\begin{array}{l}\text { Western wheatgrass (Agropyron } \\
\text { smithii) }\end{array}$ & $0.36+0.92 \mathrm{x}$ & 0.96 & 71 \\
$\begin{array}{l}\text { Water sedge (Carex aquatilis) } \\
\text { Sandberg bluegrass (Poa secunda) }\end{array}$ & $0.74+0.56 \mathrm{x}$ & 0.98 & 70 \\
$\begin{array}{l}\text { Sand dropseed (Sporobolus } \\
\quad \text { cryptandrus) }\end{array}$ & $2.29+1.08 \mathrm{x}$ & 0.99 & 82 \\
$\begin{array}{l}\text { Basin big sagebrush (Artemisia } \\
\quad \text { ridentata) }\end{array}$ & $3.34+1.11 \mathrm{x}$ & 0.96 & 36 \\
$\begin{array}{l}\text { Douglas rabbitbrush (Chrysothamnus } \\
\text { visicidiflorus) }\end{array}$ & $1.96+0.50 \mathrm{x}$ & 0.97 & 33 \\
$\begin{array}{l}\text { Fireweed summer cypress (Kochia } \\
\text { scoparia) }\end{array}$ & $2.16+0.76 \mathrm{x}$ & 0.97 & 34 \\
$\begin{array}{l}\text { Desert globemallow (Sphaeralcea } \\
\text { ambigua) }\end{array}$ & $2.94+0.96 \mathrm{x}$ & 0.95 & 47 \\
\hline
\end{tabular}

I $Y$ is the estimated and $x$ is the actual percentage dry weights, and NDF is percent neutral detergent fiber. The number of observations was 20 for each regression.

percent relative densities of sand dropseed, basin big sagebrush, and desert globemallow were $3 \%, 5 \%$, and $3 \%$, respectively, higher than the actual percent dry weights $(p<0.05)$. These differences indicated that correction factors should be calculated via regression analyses for individual species if the deviations from the dry weight fraction are considered important.

The usefulness of such correction factors was indicated by the estimated relative density and actual percent dry weights of all species were highly correlated. The coefficient of determination $\left(r^{2}\right)$ ranged from 0.95 to 0.99 for the 8 plants species (Table 1 ).

Spearman's rank correlation coefficients $\left(r_{\mathbf{s}}\right)$, for the ratio of the estimated relative density and the actual percent dry weight of each species, and the neutral detergent fiber fraction were not significant. The $\left(r_{\mathrm{s}}\right)$ value indicated that the estimated percent relative density of each species and its fiber content were independent. Consequently, no species was considered over or underestimated due to its high or low fiber content.

\section{Discussion}

Voth and Black (1973) stated that the thinner the cell wall of a specics the more likely it might be underestimated by the microscopic technique. In this study western wheatgrass and water sedge, having well-developed cell patterns and NDF fractions of $70 \%$ and $73 \%$, respectively, were accurately quantified. On the other hand, sandberg bluegrass, having easily identifiable stomates, well-developed cell walls, and a fiber fraction of $70 \%$, was significantly underestimated. Douglas rabbitbrush and fireweed summer cypress had NDF contents of $30 \%$ and $34 \%$, the lowest among all plants studied. However, both plant species were accurately estimated. Other species of low NDF fraction like basin big sagebrush (36\%) and desert globemallow (47\%) were significantly overestimated. Thus, cell wall thickness and the easily identifiable cell patterns had no effect on the quantification of plant species used in this study.

Kie et al. (1980) and Sanders et al. (1980) stated that those species with easily observable identification characteristics, such as stellate trichomes, may be overestimated by microscopic analyses.
In this study Douglas rabbitbrush and fireweed summer cypress, having an easily identifiable multicellular and finger-like trichome, respectively, were both accurately estimated. However, basin big sagebrush with a T-shape trichome and desert globemallow with a star-shaped trichome were both significantly overestimated.

McInnis et al. (1981) stated that grasses are overestimated and forbs are underestimated in herbivore diets estimated by the microscope analysis of feces technique. In this study one grass and the sedge were accurately quantified (western wheatgrass, water sedge), one grass was underestimated (sandberg bluegrass), and one grass overestimated (sand dropseed). On the other hand, Douglas rabbitbrush and fireweed summer cypress were accurately estimated; and basin big sagebrush and desert globemallow were overestimated. These results do not agree with the results reported by McInnis et al. (1981).

Many factors, such as slide preparation procedure and differential digestion, are known to affect the discernibility of fragments of plants on microscope slides. High coefficients of determination $\left(r^{2}\right)$ were found between the estimated percent relative density and actual percent dry weight of plant species in this study. The plant fiber fraction, easily observable identification clues, and the combination of grasses and forbs were found to have a negligible effect on quantification of fragments. However, the technician overestimated plants in low proportions and underestimated those in high proportions in this study.

Additional research on the observer's skill and training is needed. Work is needed to describe specific methods for slide sampling and microscopic field selection.

\section{Literature Cited}

Beetle, A.A. 1970. Recommended plant names. Univ. Wyoming Agr. Exp. Sta. Res. J. 31:1-24.

Dearden, B.L., and R.E. Pegau. 1972. Plant fragment discernibility in caribou rumens. Proc. of the First International Reindeer and Caribou Symposium, Biological Papers of the Univ. Alaska, Spec. Rep. No. 1:257-277.

Flinders, J.T., and R.M. Hansen. 1972. Diets and habits of jackrabbits in northeastern Colorado. Range Sci. Dep. Sci. Ser. No. 12. Colorado State Univ., Fort Collins.

Goering, H.K., and P.J. Van Soest. 1970. Forage fiber analyses. USDA, Agr. Handbook No. 379.

Holechek, J.L., and B. Gross. 1982. Training needed for quantifying simulated diets from fragmented range plants. J. Range Manage. 35:644-647.

Holechek, J.L., B. Gross, S.M. Dabo, and T. Stephenson. 1982. Effect of sample preparation, growth stage, an observer on microhistological analyses of herbivore diets. J. Wildl. Manage. 46:502-505.

Kie, J.G., D.L. Drawe, and G. Scott. 1980. Changes in diet and nutrition with increased herd size in Texas white-tailed deer. J. Range Manage. 33:28-34.

McInnis, M.L., M. Vavra, and W.C. Krueger. 1982. A comparison of four methods used to determine the diets of large herbivores. J. Range Manage. 36:302-306.

Sanders, K.D., B.E. Dahl, and G. Scott. 1980. Bite-count vs. fecal analyses for range animal diets. J. Range Manage. 33:146-149.

Sparks, D.R., and J.C. Malechek. 1968. Estimating percentage dry weight in diets using a microscope technique. J. Range Manage. 21:164-165.

Vavra, M., and J.L. Holechek. 1980. Factors influencing microhist ological analyses of herbivore diets. J. Range Manage. 33:371-373.

Voth, E.H., and H.C. Black. 1973. A histologic technique for determining feeding habits of small herbivores. J. Wildl. Manage. 37:223-231. 